\title{
Soluble TNF Superfamily Member 12 Measurement
}

National Cancer Institute

\section{Source}

National Cancer Institute. Soluble TNF Superfamily Member 12 Measurement. NCI

Thesaurus. Code C156526.

The determination of the amount of soluble TNF superfamily member 12 present in a sample. 